\title{
PENGARUH MODEL PEMBELAJARAN LEARNING CYCLE TERHADAP KETERAMPILAN BERPIKIR KRITIS SISWA
}

\author{
Aryani Novianti, Meiry Fadilah Noor, Baiq Hana Susanti \\ Pendidikan Biologi, Fakultas Ilmu Tarbiyah dan Keguruan UIN Syarif Hidayatullah
}

\begin{abstract}
The purpose of this research was to know the effect of the Learning Cycle model on concept of the Human Digestive System to critical thinking skills of students. The 5E (Engagement, Exploration, Explanation, Elaboration and Evaluation) Learning Cycle model is adopted for this research. The VIII grade students of SMP N 9 South Tangerang City functioned as the population of this research, while the sample were the VIII grade students in classes 7 (38 students) and 8 (38 students) of the same school. Sampling techniques in the study was conducted by using purposive sampling technique. The research method used in this research is the method of Quasi-experimental research design with research design of the nonequivalent control group design. A written test in the form of multiple choice and essay was used to measure the critical thinking skills of the subjects. An observation sheet was used by the teacher to observed the implementation of the Learning Cycle model and the learning and critical thinking skills that were developed by the students. For data analysis, t-test was used. The results showed the value of $t_{\text {count }}$

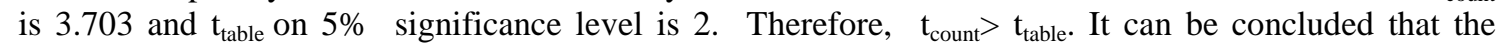
application of Learning Cycle model in the Human Digestive System concept has an influence in the students' critical thinking skills.
\end{abstract}

Keywords: Quasi-experimental research design, learning cycle model, critical thinking skills.

\begin{abstract}
Abstrak
Tujuan dari penelitian ini adalah untuk mengetahui pengaruh model pembelajaran Learning Cycle pada konsep Sistem Pencernaan pada Manusia terhadap keterampilan berpikir kritis siswa. Adapun model pembelajaran Learning Cycle yang diterapkan adalah jenis 5E (Engangement, Exploration, Explanation, Elaboration dan Evaluation). Populasi dari penelitian ini adalah seluruh siswa kelas VIII SMP N 9 Kota Tangerang Selatan sedangkan sampelnya adalah seluruh siswa di kelas VIII 7 (38 orang) dan VIII 8 (38 orang) SMP N 9 Kota Tangsel. Teknik pengambilan sampel dalam penelitian ini dilakukan dengan teknik Sampling Purposive. Metode penelitian yang digunakan dalam penelitian ini adalah metode penelitian Quasi-eksperimental design dengan desain penelitian berupa nonequivalent control group design. Instrumen yang digunakan berupa tes tertulis berupa pilihan ganda dan esai yang ditujukan untuk mengukur keterampilan berpikir kritis. Sedangkan lembar observasi digunakan untuk mengamati keterlaksanaan model pembelajaran Learning Cycle oleh guru dan keterampilan berpikir kritis yang tergali oleh siswa. Analisis data menggunakan uji-t diperoleh hasil $t_{\text {hitung }}$ 3,703 dan $t_{\text {tabel }}$ pada taraf signifikansi $5 \%$ sebesar 2, maka $t_{\text {hitung }}>\mathrm{t}_{\text {tabel }}$. Hal ini dapat disimpulkan bahwa penerapan model pembelajaran Learning Cycle pada konsep Sistem Pencernaan pada Manusia berpengaruh terhadap keterampilan berpikir kritis siswa.
\end{abstract}

Kata Kunci: Penelitian Quasi-eksperimental design, model pembelajaran Learning Cycle, keterampilan berpikir kritis.

\section{PENDAHULUAN}

Perkembangan Ilmu Pengetahuan Teknologi dan Sains (IPTEKS) yang semakin berkembang pesat merupakan sebuah kemajuan yang dapat meningkatkan kesejahteraan hidup masyarkat. Namun hal tersebut juga merupakan tantangan bagi kita untuk dapat bersaing seacara global dengan masyarakat dunia. Dalam kondisi tersebut kita dituntut untuk dapat meningkatkan kualitas SDM, dengan kata lain berarti kita dituntut untuk meningkatkan mutu pendidikan. Bahwasanya menilai kualitas SDM bangsa secara umum dapat dilihat dari mutu pendidikan bangsa tersebut (Kusnandar, 2007). Oleh karena itu, pendidikan dewasa ini harus diarahkan pada peningkatan daya saing bangsa agar mampu berkompetisi dalam persaingan global. Hal ini bisa tercapai jika pendidikan di sekolah diarahkan tidak semata-mata pada penguasaan dan pemahaman konsep-konsep ilmiah, tetapi juga pada peningkatan kemampuan dan keterampilan berpikir siswa, khususnya keterampilan berpikir kritis (Sadia, 2008).

Peraturan Menteri Pendidikan Nasional No.23 Tahun 2006 tentang Standar Kompetensi 
Lulusan tingkat Satuan Pendidikan Dasar dan Menengah menjelaskan bahwa: (1) mencari dan menerapkan informasi dari lingkungan sekitar dan sumber-sumber lain secara logis, kritis, dan kreatif, dan (2) menunjukkan kemampuan berpikir logis, kritis, kreatif, dan inovatif, merupakan bagian dari standar kompetensi lulusan bagi siswa SMP/MTs/SMPLB/Paket B (BSNP: 2006). Maka dapat dikatakan bahwa dalam proses pembelajaran hendaknya diupayakan agar siswa dapat memiliki keterampilan berpikir, salah satunya adalah keterampilan dalam berpikir kritis.

Kenyataannya, masih teridentifikasi pembelajaran yang belum melatih keterampilan berpikir kritis siswa (Arnyana, 2007). Hal ini disebabkan oleh kurangnya pengetahuan guru terhadap model pembelajaran yang dapat melatih keterampilan berpikir, belum diketahuinya bahwa keterampilan berpikir dapat dilatih, dan belum diketahuinya cara mengukur keterampilan berpikir kritis. Akibat kurangnya kemampuan guru dalam meningkatkan keterampilan berpikir kritis berdampak negatif pada siswa, dimana siswa juga menjadi tidak terampil dalam berpikir kritis.

Model pembelajaran yang dapat memstimulus siswa dalam berpikir kritis yaitu model pembelajaran konstruktivisme (Rustaman, 2005). Siklus belajar atau disebut sebagai Learning Cycle bagian dari model pembelajaran konstruktivisme (Yatim Prianto, 2009). Adapun Learning Cycle berdasarkan proyek BSCS (Biological Science Curriculum Study) terdiri dari 5 fase yaitu fase Engagement, fase Exploration, fase Explanation, fase Elaboration, dan fase Evaluation.

Salah satu kontributor terkenal bagi perkembangan tradisi berpikir kritis adalah Robert Ennis. Definisi dari berpikir kritis menurut Ennis dalam Fisher ( 2009), adalah pemikiran yang masuk akal dan reflektif yang berfokus untuk memutuskan apa yang mesti dipercaya atau dilakukan. Adapun aspek keterampilan berpikir kritis terdiri dari memberikan penjelasan sederhana, membangun keterampilan dasar, menyimpulkan, membuat penjelasan lanjut, serta strategi dan taktik yang terdiri dari sejumlah sub aspek dan indikator (Costa, 1985).

Pada tiap fase dimungkinkan dapat menghantarkan siswa untuk berpikir kritis. Fase awal yaitu engagement guru memulai pembelajaran dengan membangkitkan minat siswa, sehingga siswa merasa tertarik dan proses pembelajaran menjadi lebih menyenangkan. Pada fase ini siswa memberikan prediksinya dengan begitu dapat terungkapkan miskonsepsi pada siswa. Pada fase exploration guru memfasilitasi siswa untuk menjawab kebenaran prediksinya dengan kegiatan praktikum ataupun studi literatur yang dipadukan dengan kerjasama dalam kelompok kecil. Pada fase exploration siswa secara tidak langsung diajak untuk belajar dengan terlibat langsung membangun pengetahuannya sendiri sekaligus melatih keterampilan berpikirnya. Terlebih lagi pada ketiga fase terakhir dari model pembelajaran Learning Cycle ini siswa diarahkan untuk mempresentasikan hasil temuannya (fase explanation), menerapkan pengetahuan dan keterampilan yang telah didapatnya pada hal baru (fase elaboration), kemudian ditutup dengan penilaian terhadap hasil proses pembelajaran siswa serta keterlaksanaan proses pembelajarannya (fase evaluation).

Perkembangan IPTEKS berdampak pada kemajuan teknologi informasi. Baik media cetak maupun elektronik memudahkan siswa mendapatkan informasi mengenai apapun. Konsep 'Sistem Pencernaan pada Manusia' diharapkan tidak hanya berupa hafalan saja, tetapi juga menstimulus siswa dalam keterampilan berpikir kritis untuk menyikapi isu atau permasalahan yang dekat hubungannya dengan kehidupan siswa maupun dengan konsep lain yang berkaitan. Misalnya pada konsep pencernaan banyak sekali bermunculan beragam produk makanan yang dipromosikan dapat meningkatkan kesehatan, bersifat praktis ataupun lainnya. Bahkan produk tersebut dapat berdampak negatif pada kesehatan seperti halnya mengkonsumsi junk food yang sering dapat menimbulkan penyakit kanker pada saluran dan kelenjar pencernaan. Oleh karena itu perlunya dilakukan penelitian untuk mengikuti dampak pembelajaran Learning Cycle terhadap Keterampilan Berpikir Kritis Siswa SMP pada Konsep Sistem Pencernaan.

\section{METODE PENELITIAN}

Penelitian ini dilakukan dengan menggunakan metode penelitian eksperimen jenis quasi experimental. Desain ini mempunyai kelompok kontrol, tetapi tidak dapat berfungsi sepenuhnya untuk mengontrol variabel-variabel luar yang mempengaruhi pelaksanaan eksperimen. Adapun desain penelitian yang digunakan dalam penelitian ini merupakan nonequivalent control group design, dimana penentuan kelompok eksperimen maupun kelompok kontrol tidak dipilih secara random. Variabel penelitian dengan dua variabel, yaitu model pembelajaran Learning Cycle sebagai variabel bebas (variabel $\mathrm{X}$ ) dan keterampilan berpikir kritis siswa 
sebagai variabel terikat (variabel Y). Adapun fase dalam penggunaan Learning Cycle pada Gambar 1.

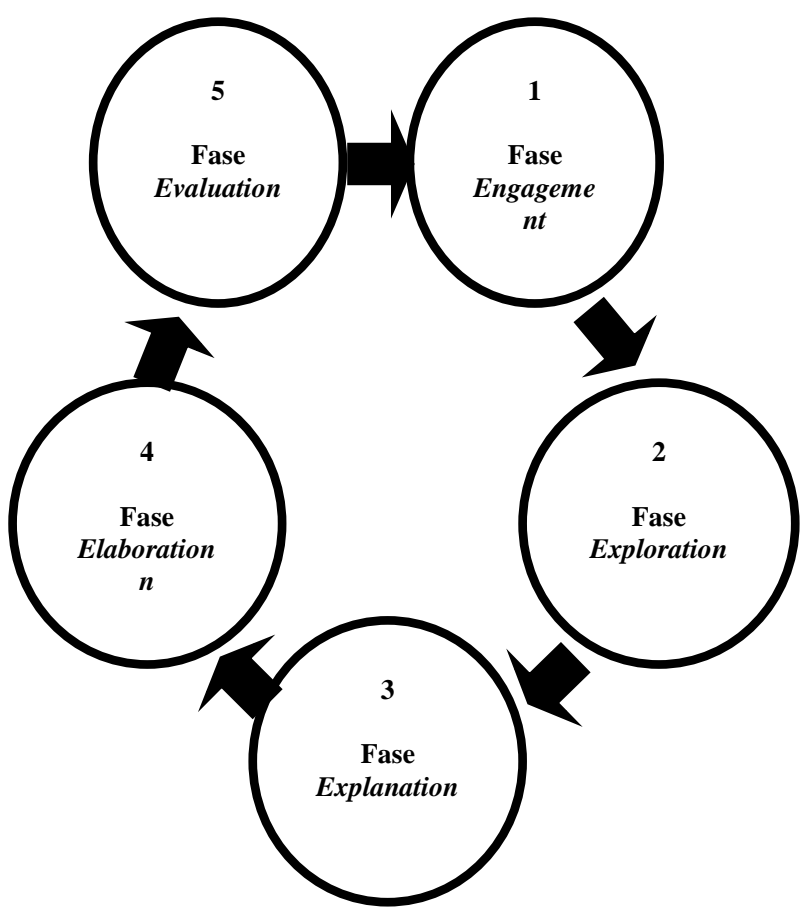

Gambar 1. Learning Cycle lima fase

Dalam penelitian ini, siswa SMP N 9 Kota Tangerang Selatan yang terdaftar dalam semester I pada tahun ajaran 2011-2012 sebagai populasi target. Populasi terjangkaunya adalah siswa SMP N 9 Tangerang Selatan kelas VIII semester I tahun ajaran 2011-2012. Sampel ditentukan dari dua kelas dari seluruh kelas VIII yang ada di SMP N 9 Kota Tangerang Selatan pada semester I tahun ajaran 2011-2012, dimana kelas VIII 8 sebagai kelas kontrol, dan kelas VIII 7 sebagai kelas eksperimen secara random.

Teknik pengumpulan data pada penelitian ini menggunakan tes tertulis berupa pilihan ganda dan esai yang ditujukan untuk mengukur keterampilan berpikir kritis. Sedangkan lembar observasi digunakan untuk mengamati keterlaksanaan model pembelajaran Learning Cycle oleh guru dan keterampilan berpikir kritis yang tergali oleh siswa.

Teknik analisis data dalam penelitian ini diawali dengan pensekoran bentuk soal pilihan ganda sejumlah 20 soal, dan esai 7 soal. Adapun indikator keterampilan berpikir kritis yang ditinjau dalam penelitian ini sejumlah 5, yaitu: mengidentifikasi atau merumuskan pertanyaan, mengidentifikasi masalah, melihat persamaan dan perbedaan, penerapan prinsip-prinsip, dan membuat generalisasi. Penskoran data bentuk soal pilihan ganda yaitu setiap butir soal yang dijawab benar diberi skor 1, dan untuk butir soal yang dijawab dengan salah diberi skor 0. Sedangkan untuk bentuk soal esai, peneliti terlebih dahulu menentukan pokok-pokok jawaban yang dikehendaki untuk setiap butir soal esai beserta penskorannya. Kemudian data diuji kenormalitasannya dengan uji Liliefors, dan uji Fisher untuk menguji kehomogenannya pada taraf signifikansi 0,05. Selanjutnya pengujian hipotesis dilakukan dengan menggunakan uji-t.

Pada penelitian ini juga digunakan dua jenis lembar observasi yaitu mengamati keterlaksanaan penerapan model pembelajaran Learning Cycle oleh peneliti, peneliti berperan sebagai guru dan yang kedua untuk mengamati keterampilan berpikir kritis siswa yang tergali dalam proses pembelajaran bermodel tersebut. Keduanya diisi oleh pengamat pada setiap kali pertemuan proses pembelajaran. Adapun hasil pengamatan dari kedua lembar observasi tersebut diolah dengan menghitung persentasenya.

\section{HASIL DAN PEMBAHASAN}

Pada penelitian ini dikumpulkan dua jenis data, yaitu data kualitatif dan kuantitatif. Adapun data kuantitatif berupa tes bentuk pilihan ganda sejumlah 20 soal dan bentuk esai sejumlah tujuh soal berindikator keterampilan berpkir kritis. Kemudian data kualitatif berupa lembar observasi keterlaksanaan proses pembelajaran. Berdasarkan hasil dari pengolahan data berupa tes keterampilan berpikir kritis yang diujikan kepada kedua kelas sebelum dan setelah perlakuan didapatkan statistik kemampuan siswa pada Tabel 1.

Tabel 1. Deskripsi Data Sebelum dan Setelah Perlakuan

\begin{tabular}{lcccc}
\hline \multirow{2}{*}{ Data Statistik } & \multicolumn{2}{c}{ Eksperimen } & \multicolumn{2}{c}{ Kontrol } \\
\cline { 2 - 5 } & Pretes & Postes & Pretes & $\begin{array}{c}\text { Poste } \\
\text { s }\end{array}$ \\
\hline Nilai tertinggi & 67 & 89 & 83 & 69 \\
Nilai & 21 & 36 & 31 & 23 \\
Terendah & & & & \\
Rata-rata & 39,87 & 70,11 & 59,63 & 42,92 \\
Median & 41,5 & 70,24 & 60,2 & 40,5 \\
Modus & 45,62 & 67,9 & 64,25 & 28,66 \\
Simpangan & 11,67 & 11,003 & 13,18 & 14,4 \\
baku & & & & \\
Jumlah siswa & 38 & 38 & 38 & 38 \\
\hline
\end{tabular}

Berdasarkan hasil penelitian didapatkan rata-rata pretest pada kelas eksperimen dan kontrol berturut-turut 39,87 dan 42,92. Hal ini menunjukkan bahwa tidak terdapat perbedaan yang jauh di antara keduanya. Setelah diberikan perlakuan, didapat perbedaan yang signifikan pada rata-rata posttest. 
Pada kelas eksperimen dan kontrol didapat rata-rata posttest berturut-turut 70,11 dan 59,63. Hal ini menunjukkan bahwa penggunaan model pembelajaran Learning Cycle pada kelas eksperimen mempengaruhi keterampilan berpikir kritis siswa.

Hal tersebut sesuai dengan hasil uji-t, dimana hasil pada skor pretest menunjukkan bahwa skor pretest kelas eksperimen dan kelas kontrol tidak ada perbedaan yang signifikan $(-1<2)$. Maka dapat dinyatakan bahwa keterampilan berpikir kritis siswa di kelas kontrol dan eksperimen sebelum proses pembelajaran tidak ada perbedaan yang signifikan. Namun setelah diberi perlakuan, maka hasil uji hipotesis pada skor posttest menunjukkan bahwa terdapat perbedaan yang signifikan antara skor posttest kelas eksperimen dan kelas kontrol, dimana nilai $t_{\text {hitung }}$ lebih dari $t_{\text {tabel }}(3,495>2)$. Dengan demikian, dapat dinyatakan bahwa keterampilan berpikir kritis kelas eksperimen yang diajarkan dengan model pembelajaran Learning Cycle dengan kelas kontrol yang diajarkan dengan model pembelajaran konvensional (Direct Instructional) terdapat perbedaan yang signifikan, dimana model pembelajaran Learning Cycle lebih baik daripada di kelas kontrol.

Hasil perhitungan persentase rata-rata ketercapaian indikator keterampilan berpikir kritis pada kelas eksperimen dan kontrol dapat dilihat pada Tabel 2.

Tabel 2. Persentase (\%) Ketercapaian Keterampilan Berpikir Kritis Kelas Eksperimen dan Kelas Kontrol

\begin{tabular}{lcc}
\hline \multicolumn{1}{c}{$\begin{array}{c}\text { Indikator } \\
\text { Keterampilan Berpikir } \\
\text { Kritis }\end{array}$} & $\begin{array}{c}\text { Kelas } \\
\text { Eksperimen } \\
(\%)\end{array}$ & $\begin{array}{c}\text { Kelas } \\
\text { Kontrol } \\
(\%)\end{array}$ \\
\hline $\begin{array}{l}\text { Mengidentifikasi atau } \\
\text { Merumuskan } \\
\text { pertanyaan }\end{array}$ & 48,68 & 42,11 \\
$\begin{array}{l}\text { Mengidentifikasi } \\
\text { Masalah }\end{array}$ & 57,89 & 67,11 \\
$\begin{array}{l}\text { Melihat Persamaan } \\
\text { dan Perbedaan }\end{array}$ & 71,05 & 61,84 \\
$\begin{array}{l}\text { Penerapan Prinsip- } \\
\text { prinsip }\end{array}$ & 74,78 & 62,5 \\
$\begin{array}{l}\text { Membuat Generalisasi } \\
\text { Rata-rata }\end{array}$ & 73,98 & 59,65 \\
\hline
\end{tabular}

Tabel 2 menunjukkan perbedaan persentase ketercapaian keterampilan berpikir kritis pada kelas eksperimen dan kelas kontrol. Tabel tersebut menunjukkan bahwa total rata-rata ketercapaian keterampilan berpikir kritis di kelas eksperimen mencapai $65,28 \%$ sedangkan di kelas kontrol mencapai $58,64 \%$.
Kemudian berdasarkan lima indikator, pada kelas eksperimen didapatkan persentase tertinggi pada keterampilan berpikir kritis siswa dalam penerapan prinsip-prinsip sebesar $74,78 \%$, dan persentase terendah terdapat pada indikator mengidentifikasi atau merumuskan pertanyaan sebesar 48,68 \%. Sedangkan ketercapaian keterampilan berpikir kritis per-indikator pada kelas kontrol didapat persentase tertinggi pada mengidentifikasi masalah sebesar $67,11 \%$, dan terendah pada keterampilan mengidentifikasi atau merumuskan pertanyaan sebesar $42,11 \%$.

Keterlaksanaan penerapan model pembelajaran Learning Cycle oleh guru dan keterampilan berpikir kritis siswa yang tergali dalam proses pembelajaran bermodel Learning Cycle diolah melalui lembar observasi. Observasi ini dilakukan oleh observer di kelas eksperimen, yaitu kelas VIII 7. Pengolahan data hasil observasi ini dilakukan secara persentase. Tabel 4 berikut merupakan tabel hasil pengolahan lembar observasi keterlaksanaan proses pembelajaran oleh siswa, dan guru.

Apabila ditinjau dari indikator keterampilan berpikir kritis yang diujikan, total rata-rata ketercapaian indikator keterampilan berpikir kritis pada kelas eksperimen dengan kelas kontrol terdapat perbedaan. Berdasarkan tabel 2 total ratarata ketercapaian indikator berpikir kritis pada kelas eksperimen sebesar 65,28\% sedangkan pada kelas kontrol sebesar 58,64 \%. Hal ini menunjukkan bahwa secara keseluruhan kelas eksperimen yang diajarkan dengan model pembelajaran Learning Cycle mencapai indikator keterampilan berpikir kritis yang lebih baik daripada di kelas kontrol dengan selisih sebesar 6,64\%.

Berdasarkan Tabel 3, indikator keterampilan berpikir kritis yang tergali pada siswa dalam proses pembelajaran dengan model Learning Cycle dapat dilihat dari kemunculan kegiatan oleh siswa. Adapun persentase tertinggi adalah pada kegiatan memberikan respon pada pertanyaan guru; mengajukan pertanyaan mengenai topik bahasan; menguji prediksi dan hipotesis; dan mencoba memberikan penjelasan terhadap konsep yang ditemukan mencapai $100 \%$. Kegiatan tersebut dimunculkan oleh siswa pada setiap pertemuan, sedangkan untuk kegiatan mengajukan pertanyaan mengenai pokok bahasan; mengusulkan pemecahan dan membuat keputusan; melakukan percobaan, dan atau pengamatan lanjutan mencapai 55,56\% kemudian untuk kegiatan menunjukkan pemahaman atau pengetahuan tentang konsep atau keterampilan 
yang telah didapatkannya pada fase sebelumnya mencapai $66,67 \%$. Pencapaian pada keterlaksanaan proses pembelajaram mencapai jumlah tersebut dikarenakan kegiatan tersebut tidak selalu dimunculkan oleh siswa pada setiap pertemuan.Adapun rata-rata keterlaksanaan model pembelajaran Learning Cycle oleh siswa mencapai $84,45 \%$.

Hasil observasi keterlaksanaan model pembelajaran Learning Cycle oleh guru tampak pada tabel 4. Berdasarkan tabel tersebut terlihat persentase untuk keterlaksanaan model pembelajaran Learning Cycle oleh guru mencapai $100 \%$. Hal ini dikarenakan kegiatan-kegiatan pada fase engagement, exploration, explanation, elaboration, dan evaluation dapat terlaksana semua di setiap pertemuan.

Berdasarkan tabel tersebut terlihat persentase untuk keterlaksanaan model pembelajaran Learning Cycle oleh guru mencapai $100 \%$. Hal ini dikarenakan kegiatankegiatan pada fase engagement, exploration, explanation, elaboration, dan evaluation dapat terlaksana semua di setiap pertemuan.

Model Learning Cycle yang merupakan bagian dari model pembelajaran berlandaskan konstruktivisme dapat mempengaruhi keterampilan berpikir kritis siswa, hal ini sejalan dengan teori belajar Piaget. Teori belajar Piaget yaitu berupa pemberian kesempatan kepada siswa untuk mengasimilasi informasi dengan cara mengeksplorasi lingkungan, mengakomodasi informasi dengan cara mengembangkan konsep, mengorganisasikan informasi dan menghubungkan konsep-konsep baru dengan menggunakan dan memperluas konsep yang dimiliki untuk menjelaskan suatu fenomena yang berbeda (Simpatupang, 2008). Adapun proses dari asimilasi menuju ke proses akomodasi, siswa mengalami ketidakseimbangan atau disekulibrium. Kemudian dengan proses akomodasi dan organisasi siswa mampu memahami dan merespons perstiwaperistiwa yang sebelumnya terasa membingungkan bagi mereka, sehingga terjadi proses ekuilibrasi. Dalam pandangan Piaget, ekulibrasi dan hasrat intrinsik siswa untuk meraih ekuilibrium mendorong perkembangan keterampilan berpikir dan pengetahuan yang semakin kompleks yang salah satunya adalah berpikir kritis (Ormrod, 2008). Jika teori belajar Piaget dihubungkan dengan model pembelajaran Learning Cycle 3 fase, proses asimilasi, akomodasi, dan organisasi berturut-turut disejajarkan dengan fase exploration (eksplorasi), term introduction (pengenalan konsep), dan concept application (aplikasi). Adapun prinsip teori belajar
Piaget ini pun menjadi dasar untuk model pembelajaran Learning Cycle 5E (Bybee, 2011). Berdasarkan teori Piaget tersebut, maka dapat dinyatakan bahwa model pembelajaran Learning Cycle 5E yang diterapkan dalam penelitian ini dapat mendorong perkembangan keterampilan berpikir kritis siswa.

Ketercapaian indikator keterampilan berpikir kritis yang lebih baik daripada di kelas kontrol menunjukkan Learning Cycle dapat menuntun siswa berfikir kritis (tabel 2). Hal ini diinisiasi pada awal model Learning Cycle terdapat fase engagement yang membuat siswa akan terbangkitkan minat dan rasa keingintahuannya (Wena, 2010). Walaupun data menunjukkan bahwa rata-rata persentase ketercapaian indikator mengidentifikasi atau merumuskan pertanyaan sebesar 48,68 \% (Tabel 2), keterlaksanaan model Learning Cycle oleh guru dan tergalinya keterampilan berpikir kritis siswa keduanya mencapai $100 \%$. Guru cenderung melontarkan pertanyaan daripada mengungkapkan permasalahan untuk diidentifikasi atau dirumuskan pertanyaannya oleh siswa. Namun tahapan ini efektif digunakan untuk melihat ada tidaknya miskonsepsi pada siswa (Bybee, 2011).

Fase kedua dari Learning Cycle yaitu fase exploration siswa dibangun pengetahuannya secara mandiri melalui kelompok kecil dengan menguji prediksinya yang muncul di fase engagement melalui berbagai kegiatan. Kegiatan yang telah dilakukan seperti praktikum, demonstrasi, ataupun studi literatur dan pengerjaan lembar kerja siswa. Siswa yang semula mengalami ketidakseimbangan atau kebingungan dapat mengalami keseimbangan kembali dengan mengidentifikasi masalah. Namun rata-rata persentase ketercapaian indikator mengidentifikasi masalah pada kelas eksperimen lebih rendah $(57,89 \%)$ daripada kelas kontrol $(67,11 \%)$. Hal ini diduga karena dalam proses pelaksanaan fase exploration indikator mengidentifikasi masalah tidak didefinisikan kepada siswa secara langsung, dengan kata lain tidak secara eksplisit dikemukakan kepada siswa. Sehingga ratarata persentase ketercapaian indikator mengidentifikasi masalah termasuk rendah pula. Walaupun berdasarkan hasil observasi menunjukkan bahwa keterlaksanaan model pembelajaran Learning Cycle oleh guru dan tergalinya keterampilan berpikir kritis siswa keduanya mencapai sebesar $100 \%$. Pada fase ini siswa cenderung menguji prediksinya saja daripada mengidentifikasi masalah secara langsung. 
Tabel 3. Hasil Observasi Keterlaksanaan Model Pembelajaran Learning Cycle 5E oleh Siswa

\begin{tabular}{|c|c|c|c|}
\hline Fase Learning Cycle-5E & $\begin{array}{c}\text { Keterampilan Berpikir } \\
\text { Kritis } \\
\text { yang Tergali }\end{array}$ & Kegiatan Siswa & $\begin{array}{c}\text { Persentase } \\
(\%)\end{array}$ \\
\hline Fase Engangement & $\begin{array}{l}\text { Mengidentifikasi/ } \\
\text { merumuskan pertanyaan }\end{array}$ & $\begin{array}{l}\text { Memberikan respons } \\
\text { terhadap pertanyaan guru. } \\
\text { Mengajukan pertanyaan } \\
\text { mengenai topik bahasan. }\end{array}$ & 100 \\
\hline Fase Exploration & $\begin{array}{l}\text { Mengidentifikasi masalah } \\
\text { Melihat persamaan dan } \\
\text { perbedaan }\end{array}$ & $\begin{array}{l}\text { Menguji prediksi dan } \\
\text { hipotesis. }\end{array}$ & 100 \\
\hline Fase Explanation & Membuat generalisasi & $\begin{array}{l}\text { Mencoba memberi } \\
\text { penjelasan terhadap } \\
\text { konsep yang ditemukan. }\end{array}$ & 100 \\
\hline Fase Elaboration & Penerapan prinsip-prinsip & $\begin{array}{l}\text { Mengajukan pertanyaan } \\
\text { mengenai pokok bahasan. } \\
\text { Mengusulkan pemecahan } \\
\text { dan membuat keputusan. } \\
\text { Melakukan percobaan, dan } \\
\text { atau pengamatan lanjutan. }\end{array}$ & 55,56 \\
\hline Fase Evaluation & Membuat generalisasi & $\begin{array}{l}\text { Menunjukkan pemahaman } \\
\text { atau pengetahuan tentang } \\
\text { konsep atau keterampilan } \\
\text { yang telah didapatkannya } \\
\text { pada fase sebelumnya. }\end{array}$ & 66,67 \\
\hline
\end{tabular}

Tabel 4. Hasil Observasi Keterlaksanaan Model Pembelajaran Learning Cycle 5E oleh Guru

\begin{tabular}{|c|c|c|}
\hline $\begin{array}{l}\text { Tahap } \\
\text { Learning } \\
\text { Cycle } 5 E\end{array}$ & Kegiatan Guru & $\begin{array}{c}\text { Persentase } \\
(\%)\end{array}$ \\
\hline $\begin{array}{c}\text { Tahapan } \\
\text { Engangement }\end{array}$ & 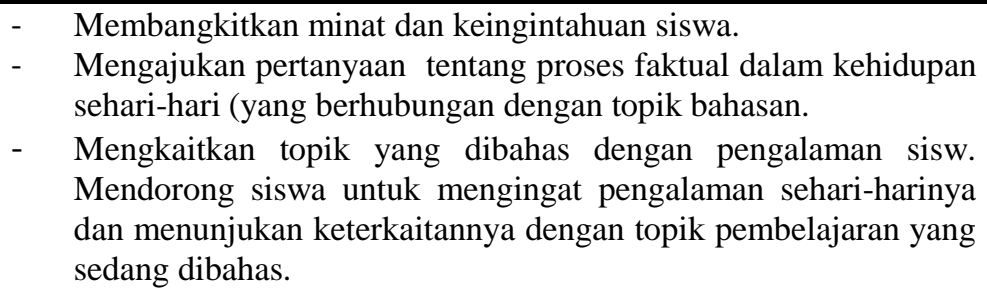 & 100 \\
\hline $\begin{array}{c}\text { Tahap } \\
\text { Exploration }\end{array}$ & $\begin{array}{l}\text { - Membentuk kelompok, memberi kesempatan untuk kerja sama } \\
\text { dalam kelompok kecil secara mandiri. } \\
\text { - } \quad \text { Guru berperan sebagai fasilitator }\end{array}$ & 100 \\
\hline $\begin{array}{c}\text { Tahap } \\
\text { Explanation }\end{array}$ & 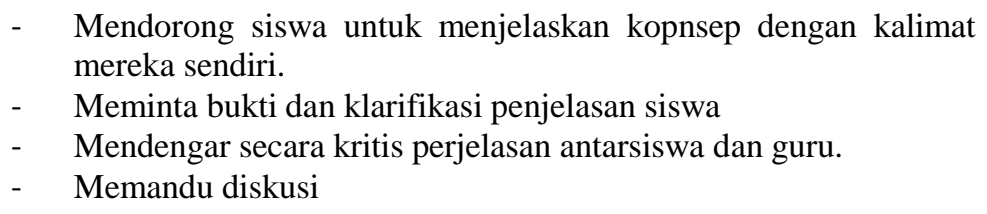 & 100 \\
\hline $\begin{array}{c}\text { Tahap } \\
\text { Evaluation }\end{array}$ & $\begin{array}{l}\text { - Mengamati pengetahuan atau pemahaman siswa dalam hal } \\
\text { menerapkan konsep baru. } \\
\text { - } \quad \text { Mendorong siswa melakukan evaluasi diri } \\
\text { - Mendorong siswa memahami kekurangan/kelebihannya dalam } \\
\text { kegiatan pembelajaran. }\end{array}$ & 100 \\
\hline
\end{tabular}


Pada indikator melihat persamaan dan perbedaan, rata-rata persentase ketercapaian indikator ini mencapai sebesar 71,05\%. Pada fase exploration siswa dapat melihat persamaan dan perbedaan. Hal ini diduga siswa difasilitasi oleh guru melalui kegiatan praktikum pada pertemuan pertama, kegiatan demonstrasi pada pertemuan kedua, dan studi literatur pada pertemuan ketiga. Dimana siswa terlibat aktif dalam beragam kegiatan yang memfasilitasinya untuk mengkonstruk pengetahuannya secara langsung. Sehingga untuk persentase ketercapaian indikator melihat persamaan dan perbedaan lebih baik daripada persentase ketercapaian indikator mengidentifikasi masalah atau merumuskan pertanyaan dan mengidentifikasi masalah.

Pada fase explanation siswa diminta mengeneralisasikan. Hasil menunjukkan bahwa total rata-rata pencapaian indikator membuat generalisasi sebesar 73,98 \%. Dengan demikian, siswa dapat mempresentasikan hasil diskusi dengan kelompok kecilnya dengan menggunakan bahasanya sendiri (Wena, 2010).

Pada fase elaboration siswa dapat menerapkan konsep dan keterampilan yang telah mereka dapat pada fase sebelumnya dalam situasi yang baru (Bybee, 2011). Pada fase siswa tergali keterampilan berpikir kritisnya dengan penerapan prinsip-prinsip yang ditunjukkan dalam kegiatan mengajukan pertanyaan mengenai pokok bahasan, mengusulkan pemecahan dan membuat keputusan, melakukan percobaan, serta pengamatan lanjutan. Sehingga total rata-rata persentase ketercapaian indikator penerapan prinsip-prinsip mencapai sebesar 73,98\%.

Siswa yang telah melalui fase-fase sebelumnya yang membuat mereka mengalami ekuilibrasi. Dimana siswa pada fase elaboration dapat dikatakan telah membangun pengetahuannya sendiri. Adapun untuk hasil observasi keterlaksanaan Learning Cycle oleh guru mencapai sebesar $100 \%$, meskipun keterampilan berpikir kritis siswa yang tergali pada fase elaboration mencapai sebesar 55,56\%. Hal tersebut diduga karena indikator penerapan prinsip ini diharapkan dapat ditunjukkan siswa dengan munculnya kegiatan mengajukan pertanyaan mengenai pokok bahasan, mengusulkan pemecahan dan membuat keputusan, dan melakukan percobaan, dan atau pengamatan lanjutan.

Hasil observasi menunjukkan bahwa pada pertemuan kesatu dan kedua siswa belum dapat mengusulkan pemecahan dan membuat keputusan, dan melakukan percobaan, dan atau pengamatan lanjutan. Pada pertemuan pertama fase elaboration dirancang berupa kegiatan pengisian lembar kerja siswa. Dimana dalam pelaksanaannya kegiatan tersebut menstimulus siswa dalam mengajukan pertanyaan mengenai pokok bahasan, namun belum dapat menstimulus siswa dalam mengusulkan pemecahan dan membuat keputusan, dan melakukan percobaan, dan atau pengamatan lanjutan. Begitupun juga untuk pertemuan kedua yang fase elaborationnya dirancang berupa kegiatan pengisian lembar kerja siswa. Dengan kata lain diduga kegiatan yang dirancang dalam fase elaboration pada pertemuan kesatu dan kedua belum cukup memfasilitasi siswa untuk mengusulkan pemecahan dan membuat keputusan, dan melakukan percobaan, dan atau pengamatan lanjutan.

Berdasarkan tahap-tahap perkembangan kognitif Piaget, siswa SMP dikategorikan pada tahap operasional konkret. Pada tahap operasional konkret siswa dapat lebih mudah berpikir logis daripada tahap perkembangan kognitif sebelumnya. Kemudian siswa pun mampu melakukan penalaran deduktif, yaitu menarik kesimpulan-kesimpulan logis berdasarkan informasi yang diberikan kepada mereka (Ormrod, 2010) Namun sekalipun siswa yang menunjukkan pemikiran operasional konkret telah menampilkan banyak ciri pemikiran logis, perkembangan kognitif mereka belumlah sempurna. Mereka mengalami kesulitan memahami gagasangagasan abstrak, serta mengalami kesulitan menghadapi soal-soal yang banyak sekali hipotesis atau variabelnya. Meskipun ada indikator yang kurang dalam pencapaiannya, namun secara keseluruhan pada kelas eksperimen yang diajarkan dengan Learning Cycle menunjukkan total rata-rata persentase ketercapaian indikator berpikir kritis yang lebih baik daripada kelas kontrol yang diajarkan dengan model pembelajaran konvensional (Direct Instructional). Hal ini sesuai denggan Budprom et.al. (2010) yang menunjukkan, bahwa keterampilan berpikir kritis siswa secara keseluruhan dan secara aspek yang diajarkan dengan model pembelajaran Learning Cycle lebih baik dibandingkan siswa yang diajarkan dengan intruksi buku panduan guru. Laporan Armiza (2007) menunjukkan, bahwa model pembelajaran siklus belajar dengan abduktif empiris juga dapat meningkatkan keterampilan berpikir kritis siswa SMP. 


\section{PENUTUP}

\section{Simpulan}

Berdasarkan hasil penelitian dan analisa data penelitian, maka dapat disimpulkan bahwa penerapan model pembelajaran Learning Cycle pada konsep Sistem Pencernaan pada Manusia berpengaruh positif terhadap keterampilan berpikir kritis siswa kelas VIII, yaitu $(3,495>2)$ dengan tingkat kepercayaan 0,95 . Dimana persentasi pencapaian indikator terbesar adalah penerapan prinsip sebesar $74,78 \%$.

Berdasarkan hasil observasi mengenai keterlaksanaan model pembelajaran Learning Cycle dapat disimpulkan bahwa guru dapat menerapkan setiap kegiatan yang diharapkan muncul dalam proses pembelajaran. Adapun rata-rata persentase keterampilan berpikir kritis yang tergali pada siswa sebesar 84,45 \%. Dengan demikian berdasarkan hasil observasi tersebut menunjukkan bahwa model pembelajaran Learning Cycle dapat menggali keterampilan berpikir kritis siswa

\section{Saran}

Adapun saran yang diajukan yaitu untuk pencapaian keterampilan berpikir kritis yang lebih baik pada indikator mengidentifikasi atau merumuskan pertanyaan, dan mengidentifikasi masalah dapat dilakukan dengan prosedural yang dilakukan secara eksplisit. Prosedural itu seperti pemberian masalah dalam bentuk pertanyaanpertanyaan yang dekat dengan kehidupan siswa dan diarahkan untuk mengidentifikasi masalah yang akan diamati pada fase exploration. Dengan demikian siswa dapat memahami dan memiliki keterampilan berpikir kritis khususnya pada kedua indikator tersebut.

\section{DAFTAR PUSTAKA}

Armiza. 2007. Model Siklus Belajar Abduktif Empiris untuk Meningkatkan Pemahaman Konsep dan Keterampilan Berpikir Kritis Siswa SMP pada Materi Pemantulan Cahaya. Jurnal Penelitian Pendidikan IPA 1(1).

Arnyana IBP. 2007. Penerapan Model PBL pada Pelajaran Biologi untuk Meningkatkan Kompetensi dan Kemampuan Berpikir Kritis Siswa Kelas X SMA Negeri 1 Singaraja Tahun Pelajaran 2006/2007. Jurnal Pendidikan dan Pengajaran 40( 2).
Budprom W, Paitool S, Adisak S. 2010. Effects of Learning Eanviromental Education Using the 5E-Learning Cycle with MultipleIntelligences and Teacher's Handbook Approach on Learning Achievment, Basic Science Process Skills and Critical Thinking of Grade 9 Students. Pakistan Journal of Social Sciences 7(3): 200-204.

BSNP, Standar Isi: Standar Kompetensi dan Kompetensi Dasar SMP/MTs, Jakarta.

Costa AL. 1985. Developing minds: A resource book for teaching thinking. Alexandria, VA: Association for Supervision and Curriculum Development.

Dorlince Simatupang. 2008. Pembelajaran Model Siklus Belajar. Universitas Negeri Medan.

Fisher A. 2009. Critical Thinking: An Introduction. Berpikir Kritis: Sebuah Pengantar, penerjemah oleh Hadinata, Benyamin. Jakarta. Erlangga.

Jeanne Ellis Ormrod. 2008. Educational Psychology Developing Learners. Psikologi Pendidikan Membantu Siswa Tumbuh dan Berkembang, penerjemah oleh Wahyu Indianti. Jakarta. Erlangga.

Kusnandar. 2007. Guru Profesional Implementasi Kurikulum Tingkat Satuan Pendidikan (KTSP) dan Sukses dalam Sertifikasi Guru. Jakarta. RajaGrafindo.

Made W. 2010. Strategi Pembelajaran Inovatif Kontemporer: Suatu Tinjauan Konseptual Operasional. Jakarta. Bumi Aksara.

Prianto Y. 2005. Paradigma Baru Pembelajaran: Sebagai Referensi bagi Pendidik dalam Implementasi Pembelajaran yang Efektif dan Berkualitas. Jakarta. Kencana.

Roger W. Bybee, dkk, 2011. The BSCS 5E Instructional Model:Origins and Effectiveness. www.bscs.org, diakses: 27 Juni 2011.

Rustaman N. 2005. Strategi Belajar Mengajar Biologi. Malang: UM Press.

Sadia IW. 2008. Model Pembelajaran yang Efektif untuk Meningkatkan Keterampilan Berpikir Kritis (Suatu Persepsi Guru). Jurnal Pendidikan dan Pengajaran 41(2). 